\title{
Boundary maps
}

Counties and unitary authorities in England

NUTS levels 1, 2 and 3 in England, 1998

Unitary authorities in Wales/Awdurdodau unedol yng Nghymru

NUTS levels 1, 2 and 3 in Wales, 1998/NUTS lefelau 1, 2 a 3 yng Nghymru,1 1998

NUTS levels 1, 2 and 3 in Scotland, 1998

Geographical classifications in Northern Ireland

Police Force areas in England and Wales

Health areas

Environment Agency regions

Education Authorities

174 


\section{Counties and unitary authorities in England ${ }^{1}$}

1 Hartlepoo

Middlesbrough

Redcar and Cleveland

Stockton-on-Tees

Darlington

Halton

Warrington

Blackburn with Darwen

Blackpool

East Riding of Yorkshire

11 City of Kingston upon Hull

12 North East Lincolnshire

13 North Lincolnshire

14 York

15 Derby

16 Leicester

17 Rutland

18 Nottingham

19 County of Herefordshire

20 Telford and Wrekin

21 Stoke-on-Trent

22 Luton

23 Peterborough

24 Southend-on-Sea

25 Thurrock

26 Bracknell Forest

27 Reading

28 Slough

29 West Berkshire (Newbury)

30 Windsor and Maidenhead

31 Wokingham

32 Milton Keynes

33 Brighton and Hove

34 Portsmouth

35 Southampton

36 Isle of Wight

37 Medway

8 Bath and North

East Somerset

39 City of Bristol

40 North Somerset

41 South

Gloucestershire

42 Plymouth

43 Torbay

44 Bournemouth

45 Poole

46 Swindon

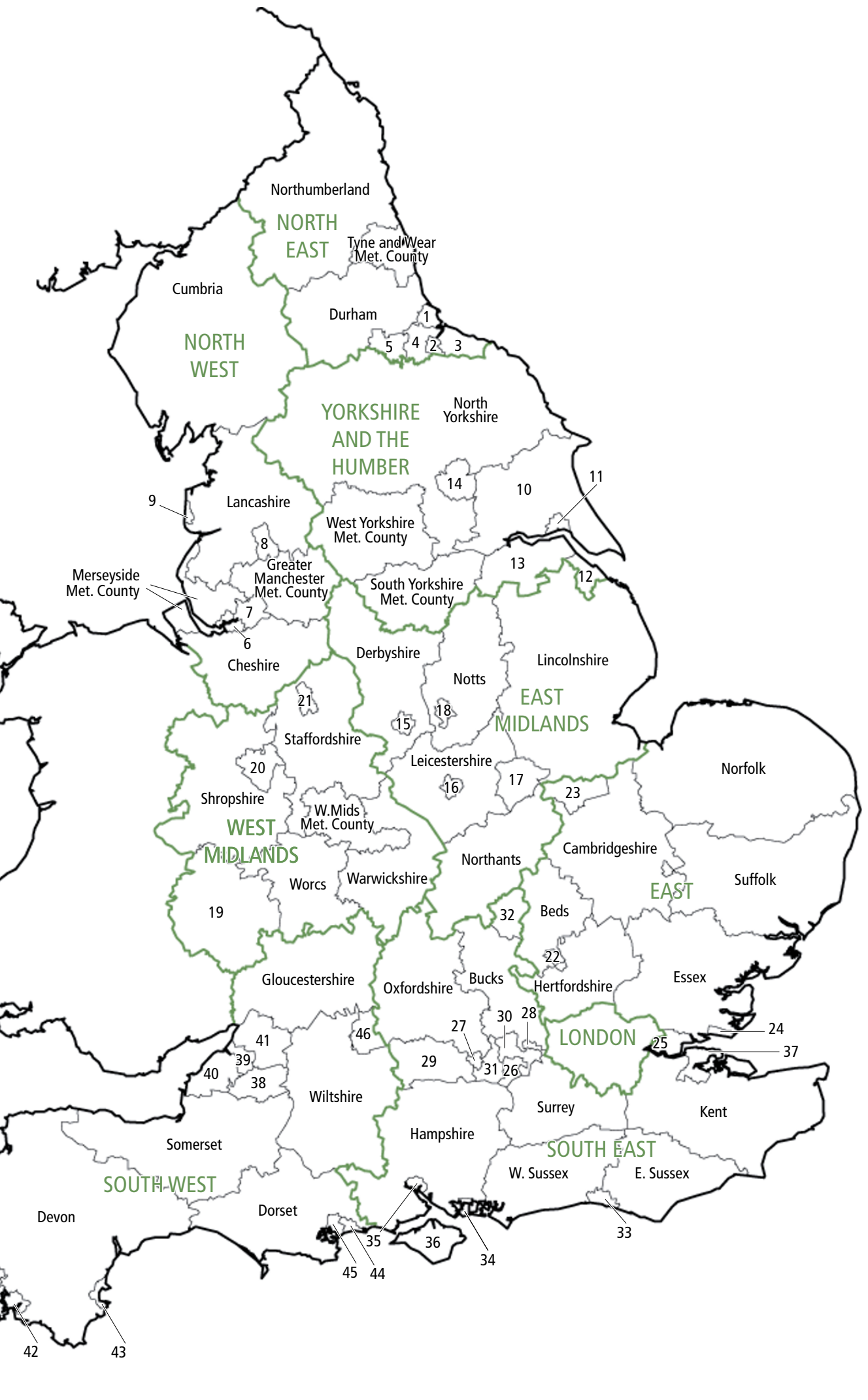

1 Local government structure as at 1 April 1998. See Notes and Definitions online. 
NUTS levels 1, 2 and 3 in England ', 1998

\section{NUTS level 3 areas}

1 South Teeside

2 Hartlepool \& Stockton

Darlington

4 Sunderland

5 Tyneside

6 Halton \& Warrington

$7 \mathrm{Gt}$ Manchester North

8 Gt Manchester South

9 Blackburn with Darwen

10 Blackpool

11 Sefton

12 Wirral

13 East Merseyside

14 Liverpool

15 East Riding of Yorkshire

16 City of Kingston upon Hull

17 North \& North East Lincolnshire

18 York

19 Leeds

21 Calderdale, Kirklees \& Wakefield

22 Sheffield

23 Barnsley,

25 South \& West Derbyshire

26 East Derbyshire

27 Leicester City

28 Leicestershire CC \& Rutland

29 Northamptonshire

30 Nottingham

31 North Nottinghamshire

32 South Nottinghamshire

33 The Wrekin

34 Stoke-on-Trent

35 Staffordshire CC

36 Walsall \& Wolverhampton

37 Birmingham

38 Coventry

39 Solihull

40 Dudley \& Sandwell

41 Luton

42 Bedfordshire CC

43 Peterborough

44 Southend-on-Sea

45 Thurrock

46 Hertfordshire

47 Inner London - East

48 Inner London - West

49 Outer London - E \& NE

59 Outer London - E \& NE

50 Outer London - South

52 Milton Keynes

53 Buckinghamshire CC

54 Brighton \& Hove
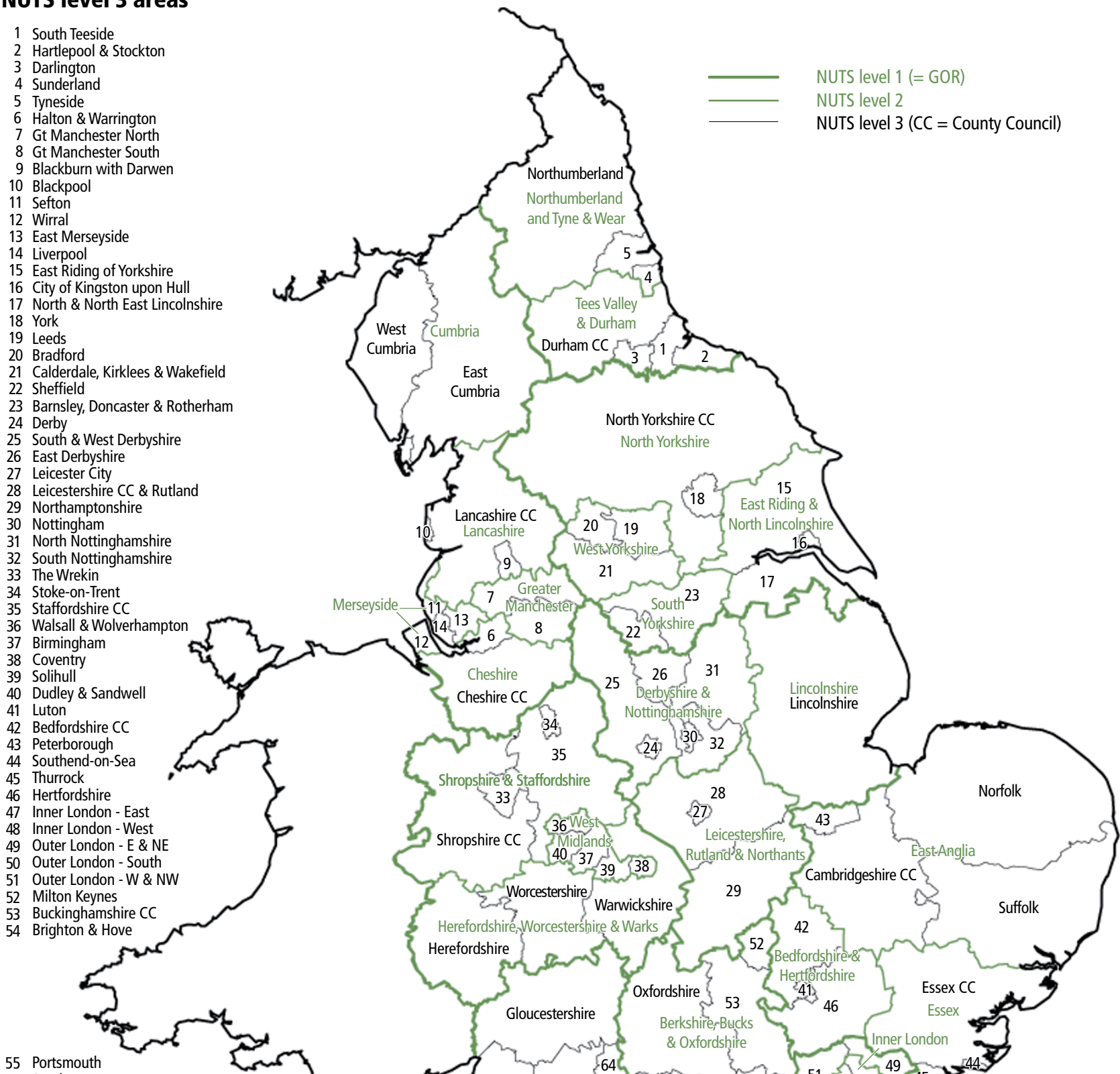

55 Portsmouth

56 Southampton

57 Medway

58 Kent CC

59 N \& NE Somerset, South Gloucestershire

60 City of Bristo

61 Plymouth

62 Torbay

63 Bournemouth \& Poole

64 Swindon
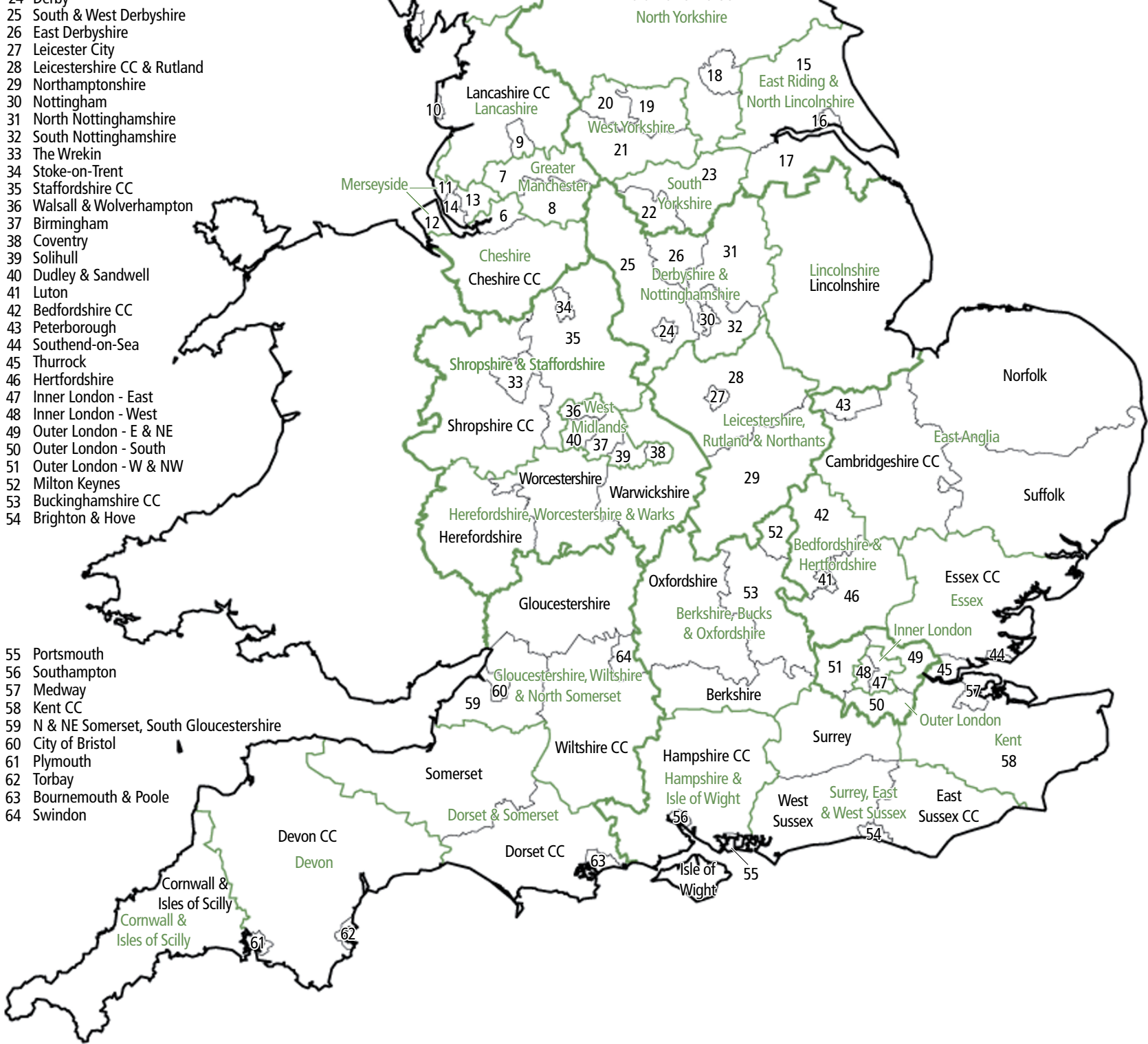

1 NUTS (Nomenclature of Units for Territorial Statistics) is a hierarchical classification of areas that provides a breakdown of the EU's economic territory. See Notes and Definitions online. 
Unitary authorities in Wales

Awdurdodau unedol yng Nghymru

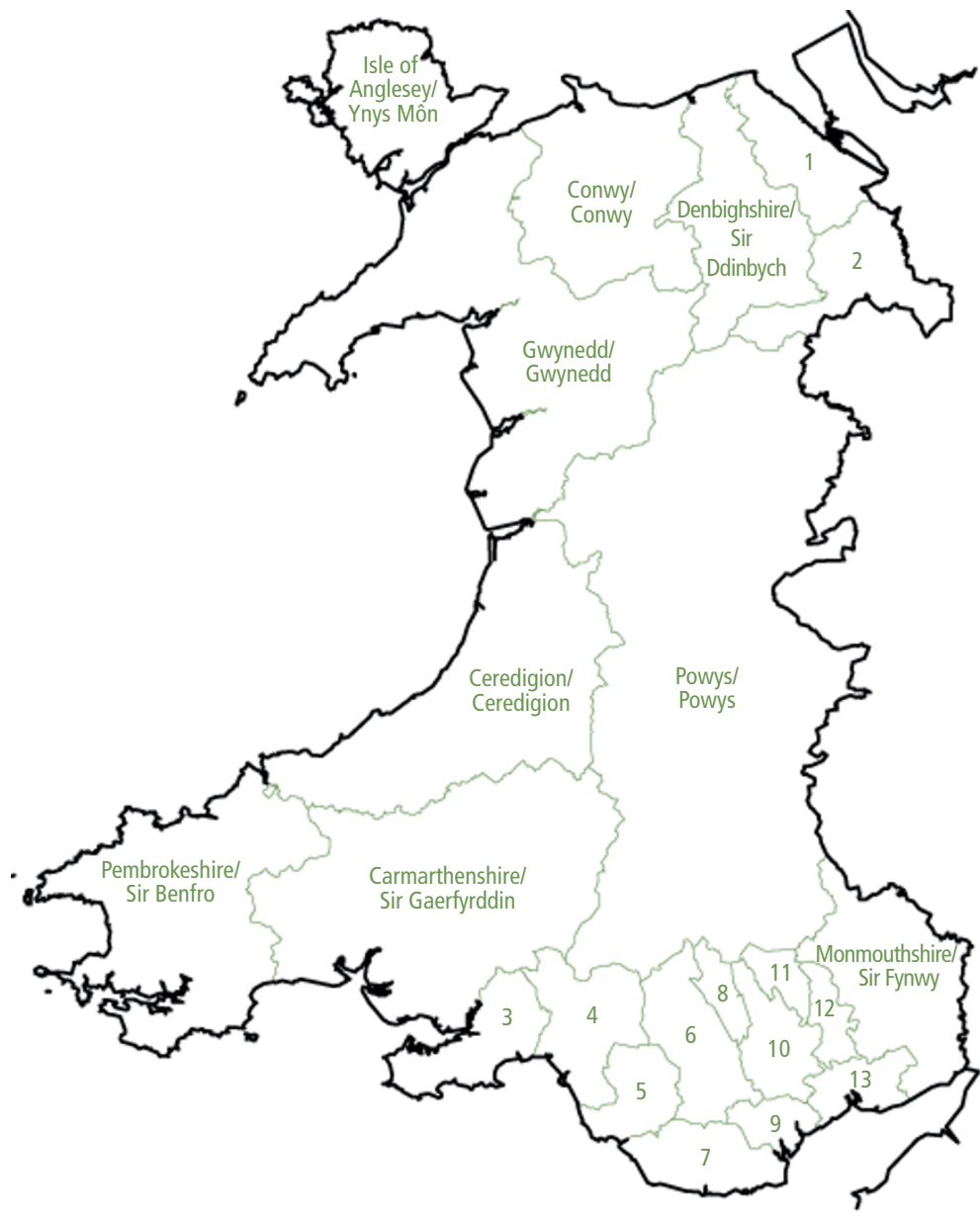

NUTS levels 1, 2 and 3 in Wales ${ }^{1}, 1998 /$

NUTS lefelau 1, 2 a 3 yng Nghymru', 1998

1 Flintshire/Sir y Fflint

2 Wrexham/Wrecsam

3 Swansea/Abertawe

4 Neath Port Talbot/Castell-nedd Port Talbot

Bridgend/Pen-y-bont ar Ogwr

6 Rhondda, Cynon, Taff/Rhondda, Cynon, Taf

7 The Vale of Glamorgan/Bro Morgannwg

8 Merthyr Tydfil/Merthyr Tudful

9 Cardiff/Caerdydd

10 Caerphilly/Caerffili

11 Blaenau Gwent/Blaenau Gwent

12 Torfaen/Tor-faen

13 Newport/Casnewydd

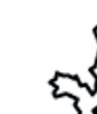

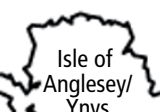
Isle of

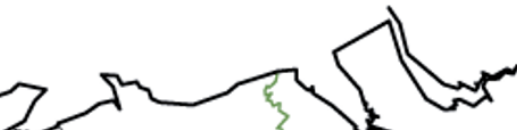
Ynys

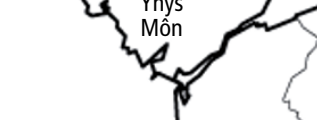

Conwy \& Denbighshire/
Conwy a Sir Ddinbych
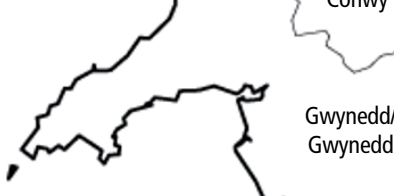

Gwynedd/

Gwynedd

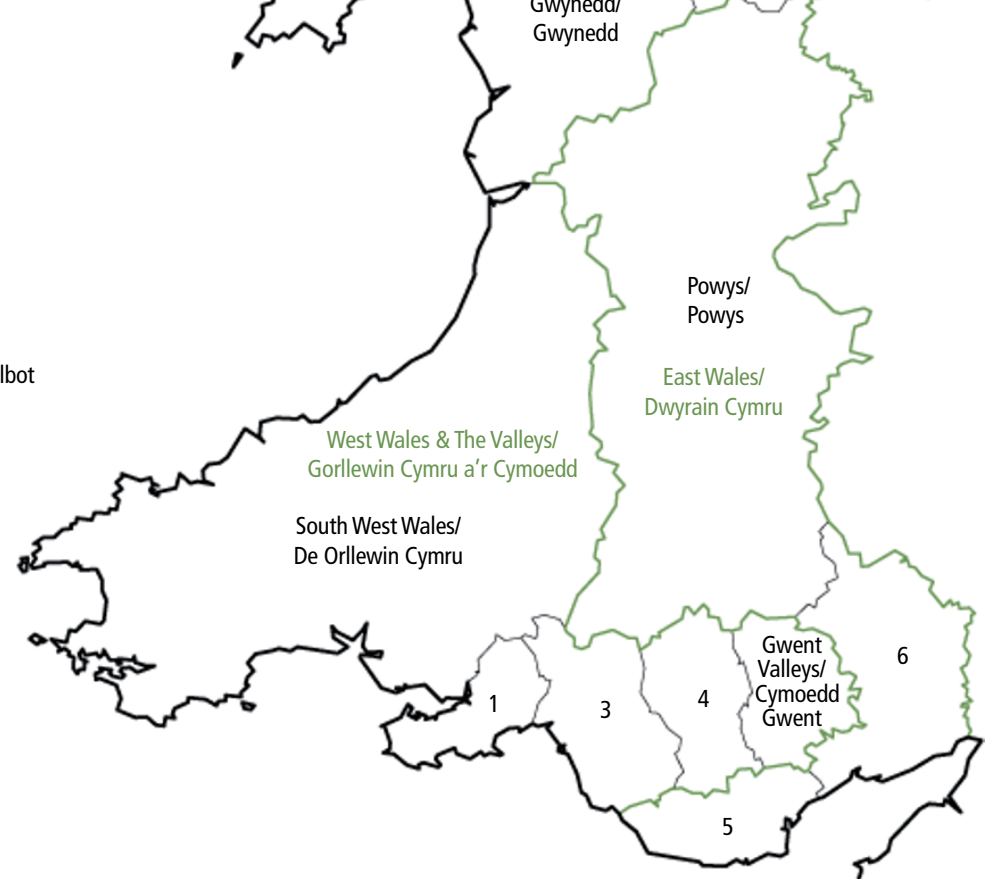

1 Swansea/Abertawe

2 Flintshire \& Wrexham/Sir y Fflint a Wrecsam

3 Bridgend \& Neath Port Talbot/Pen-y-bont ar Ogwr a Chastell-nedd Port Talbot 4 Central Valleys/Canol y Cymoedd

5 Cardiff and The Vale of Glamorgan/Caerdydd a Bro Morgannwg

6 Monmouthshire and Newport/Sir Fynwy a Chasnewydd 


\section{Councils in Scotland}
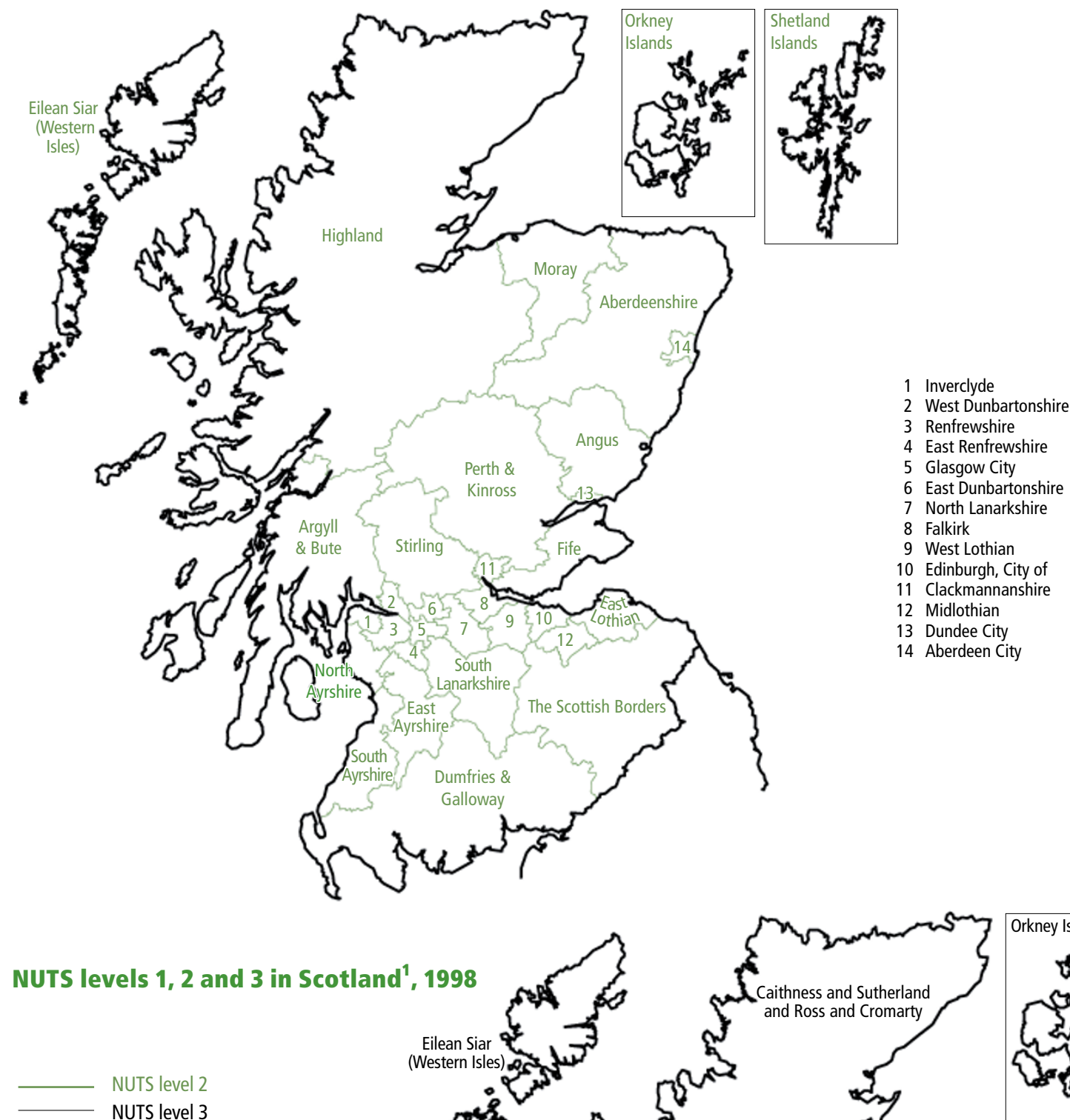

NUTS level 3

1 Lochaber, Skye and Lochalsh and Argyll and the Islands

2 Clackmannanshire and Fife

3 East and West Dunbartonshire,

Helensburgh and Lomond

4 North Lanarkshire

5 City of Edinburgh

6 East Lothian and Midlothian

7 Inverclyde, East Renfrewshire

and Renfrewshire

8 Glasgow City

9 East Ayrshire and North

Ayrshire Mainland

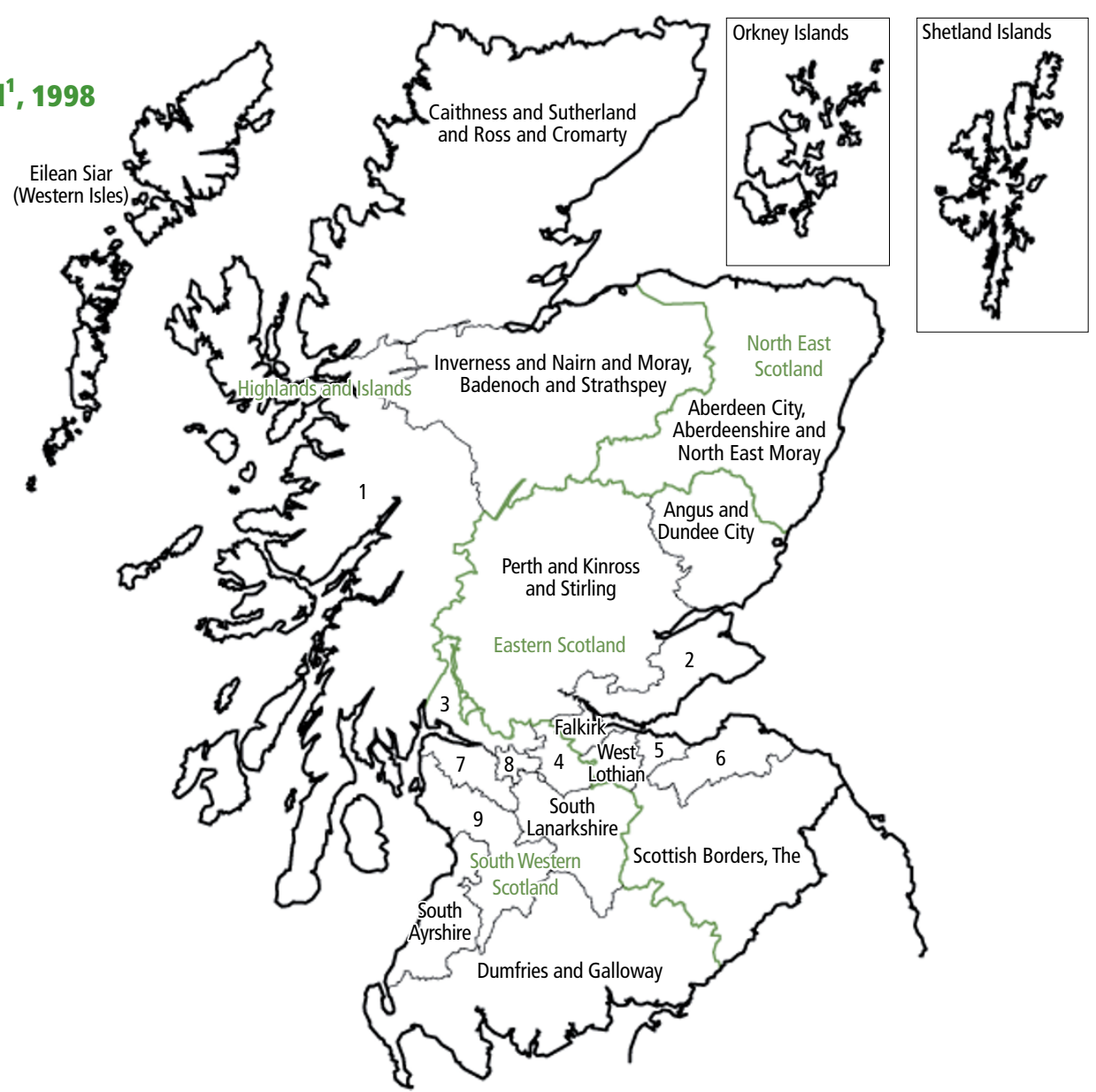

1 NUTS (Nomenclature of Units for Territorial Statistics) is a hierarchical classification of areas that provides a breakdown of the EU's economic territory. The NUTS level 1 area is the whole country. See Notes and Definitions online. 


\section{Geographical classifications ${ }^{1}$ in Northern Ireland}

Education and Library Boards

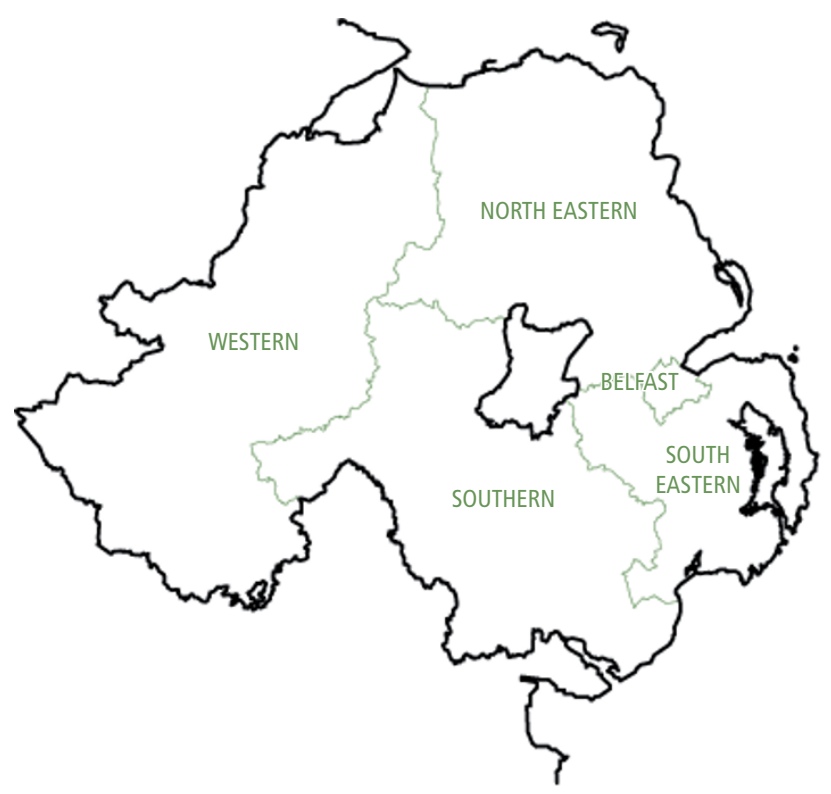

Health and Social Services Boards

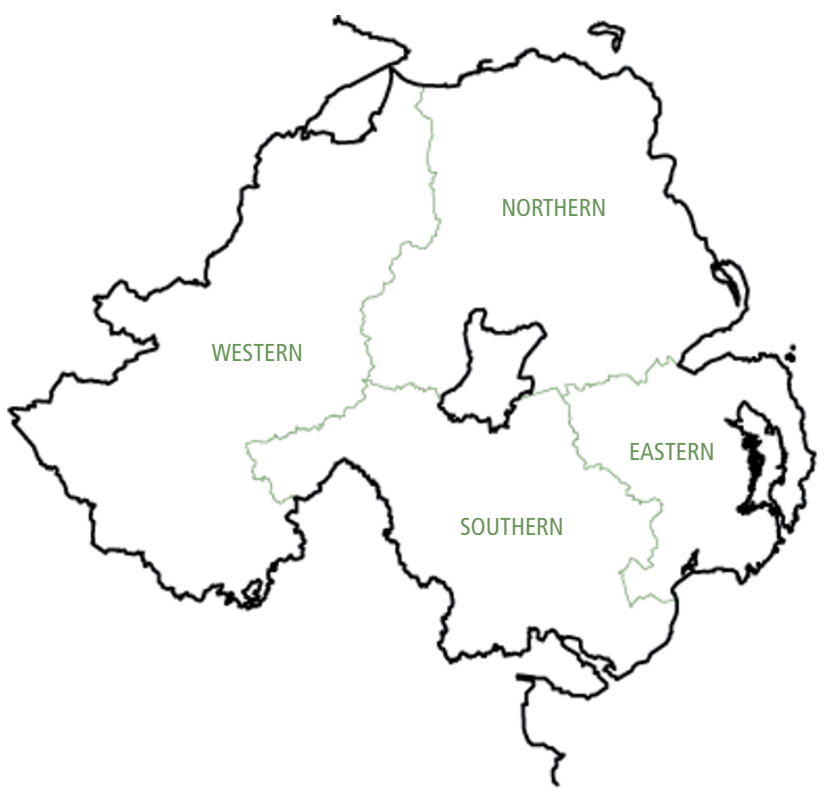

District Councils

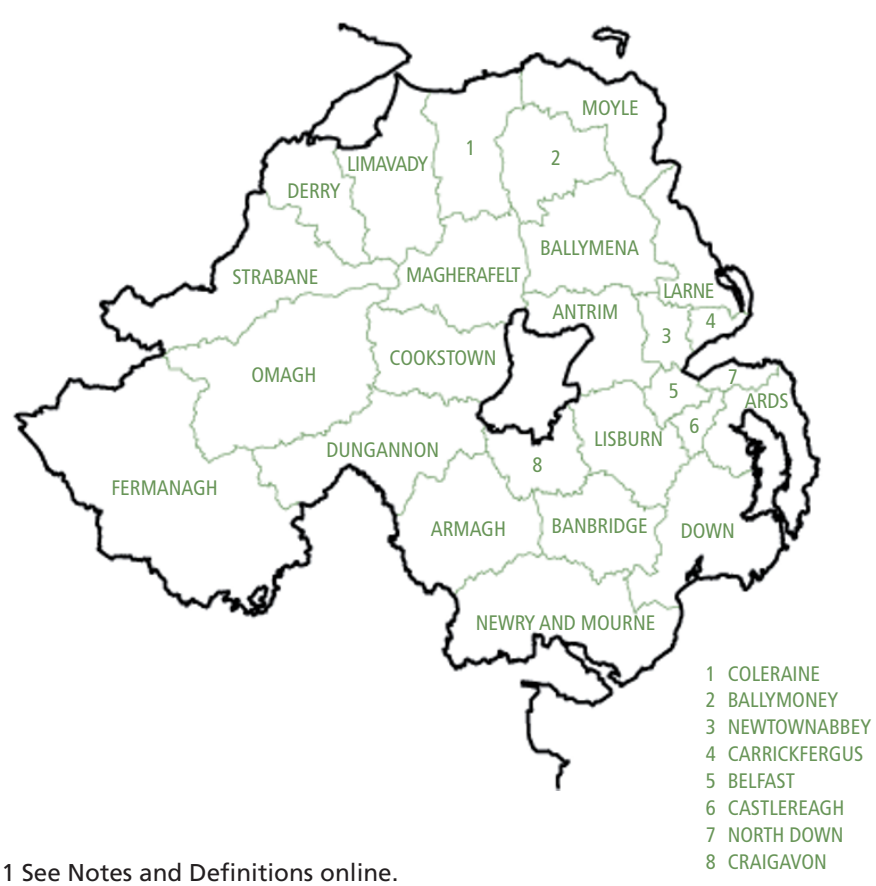

NUTS levels 1, 2 and 3 in Northern Ireland

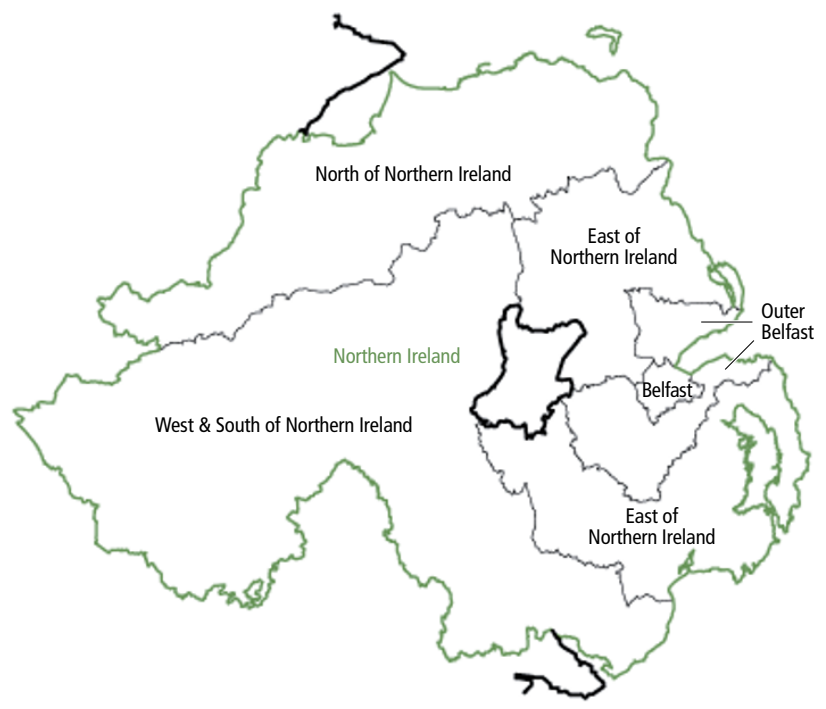

NUTS level 1 and 2 NUTS level 3 
Police areas

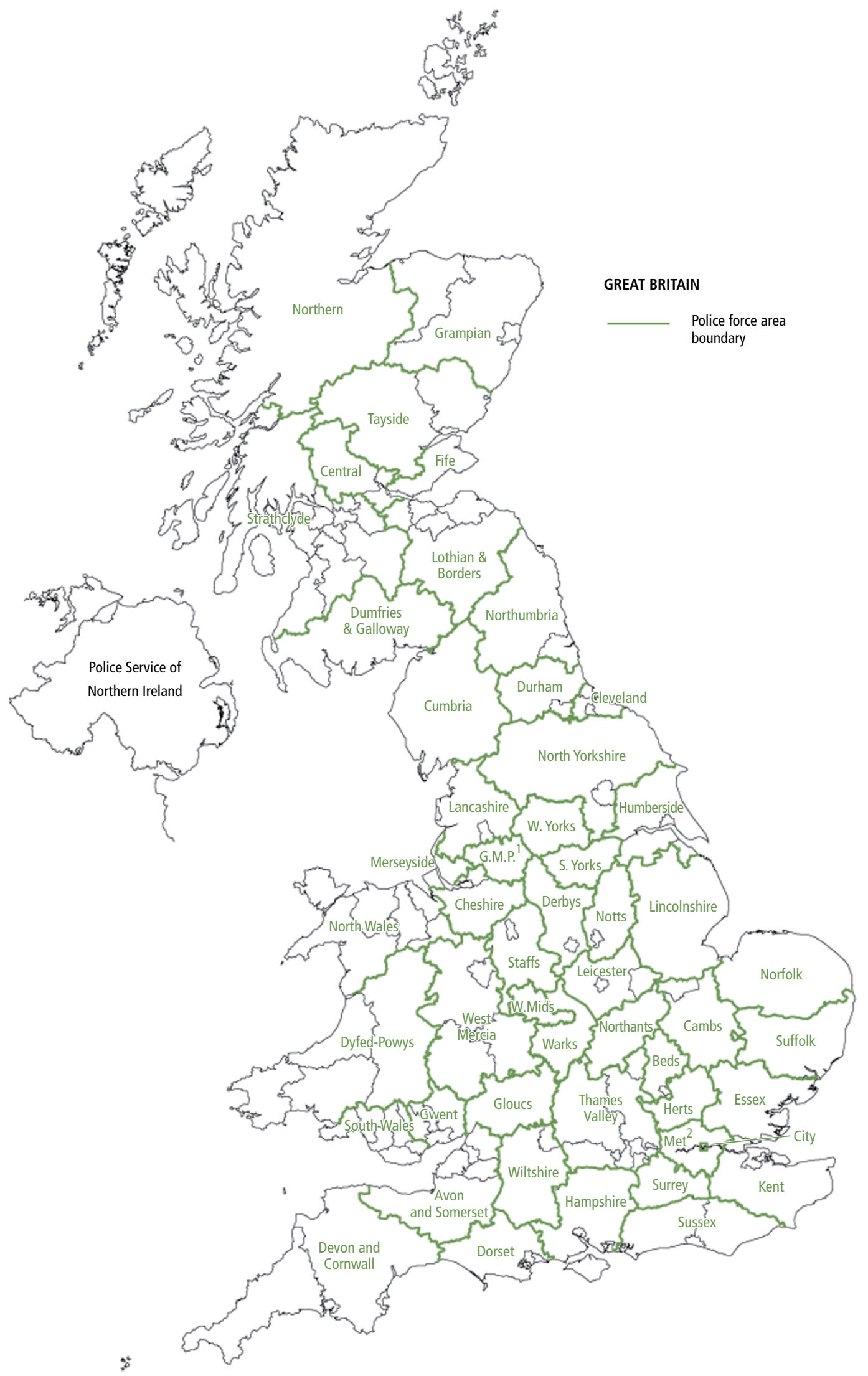

1 Greater Manchester Police.

2 Metropolitan Police. 
Health areas

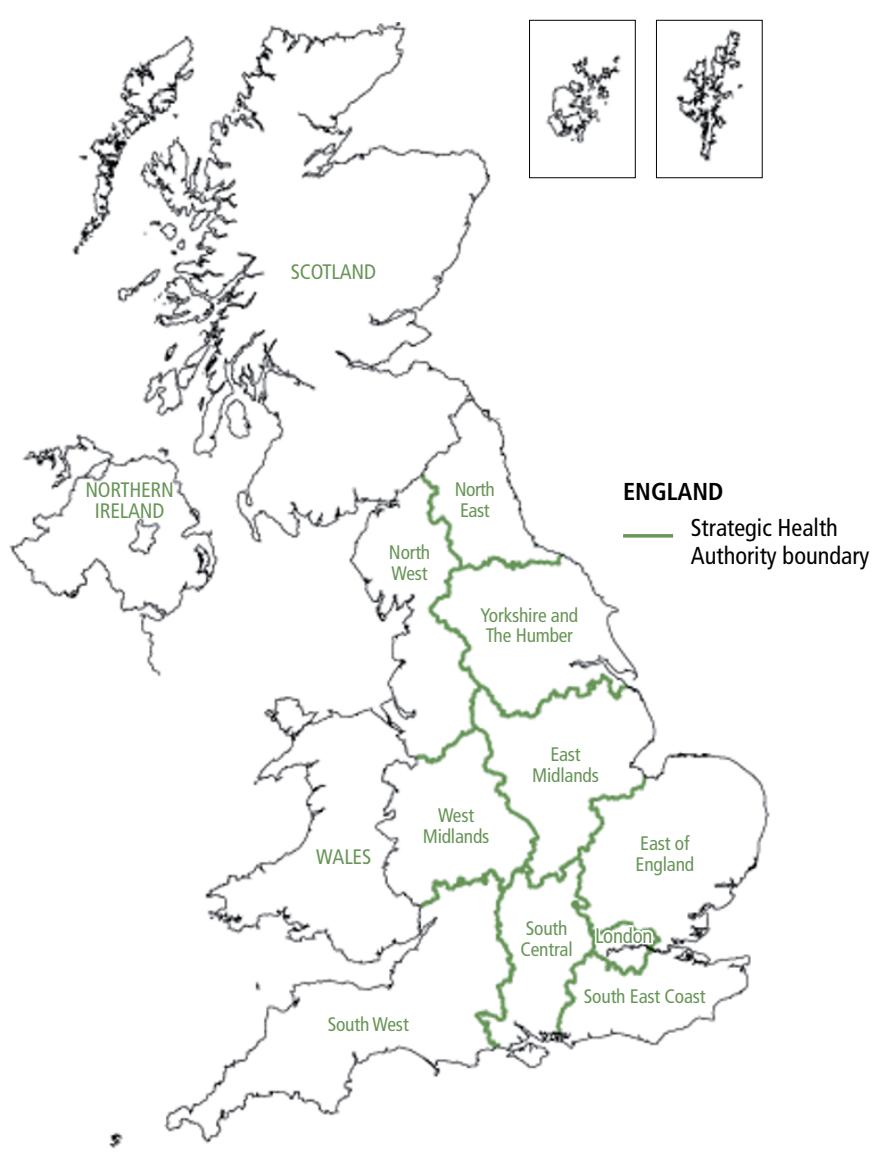

Environment Agency regions, England and Wales

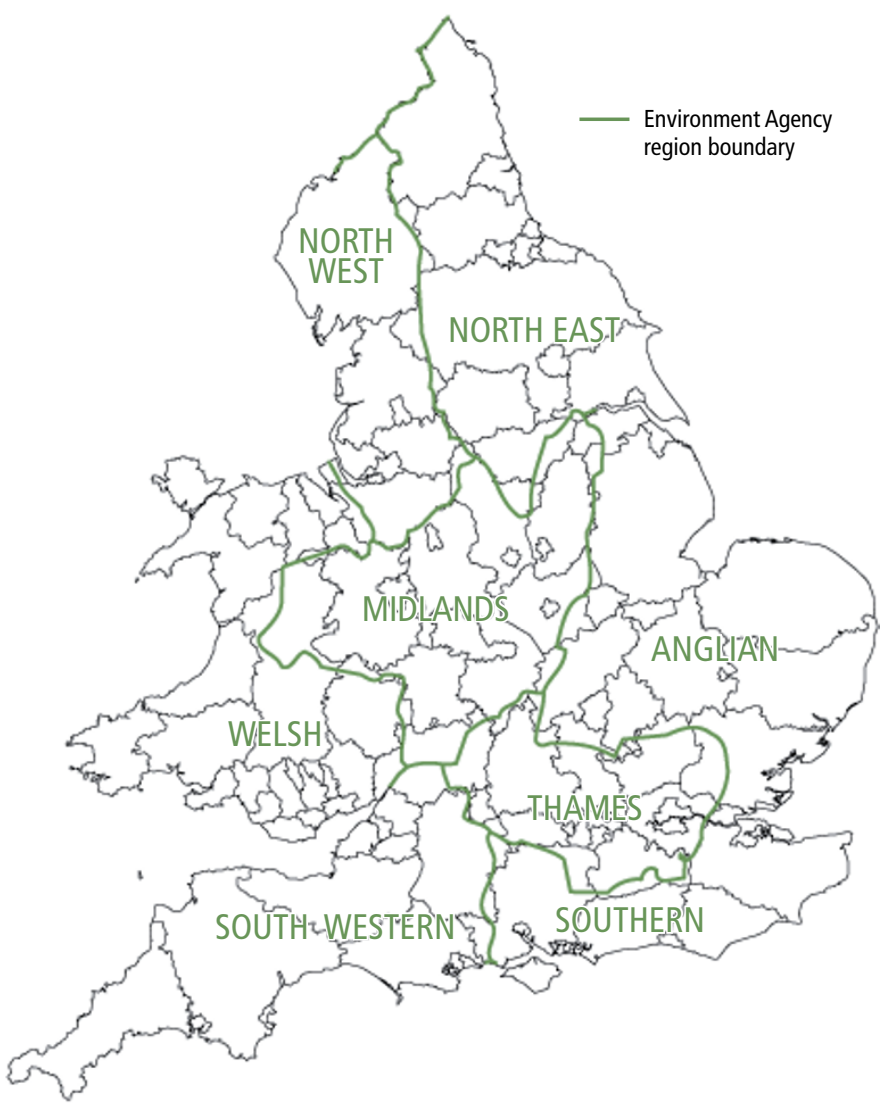


Education authorities in England

1 North Tyneside

2 Newcastle upon Tyne

3 Gateshead

4 South Tyneside

5 Sunderland

6 Hartlepool

7 Stockton-on-Tees

8 Darlington

9 Middlesbrough

10 Redcar and Cleveland

11 Kingston upon Hull

12 North Lincolnshire

13 North East Lincolnshire

14 Calderdale

15 Kirklees

16 Wakefield

17 Barnsley

18 Sheffield

19 Rotherham

20 Doncaster

21 Derby

22 Nottingham

23 Leicester

24 Rochdale

25 Oldham

26 Tameside

27 Stockport

28 Manchester

29 Bury

30 Blackburn with Darwen

31 Bolton

32 Wigan

33 Salford

34 Trafford

35 Warrington

36 St Helens
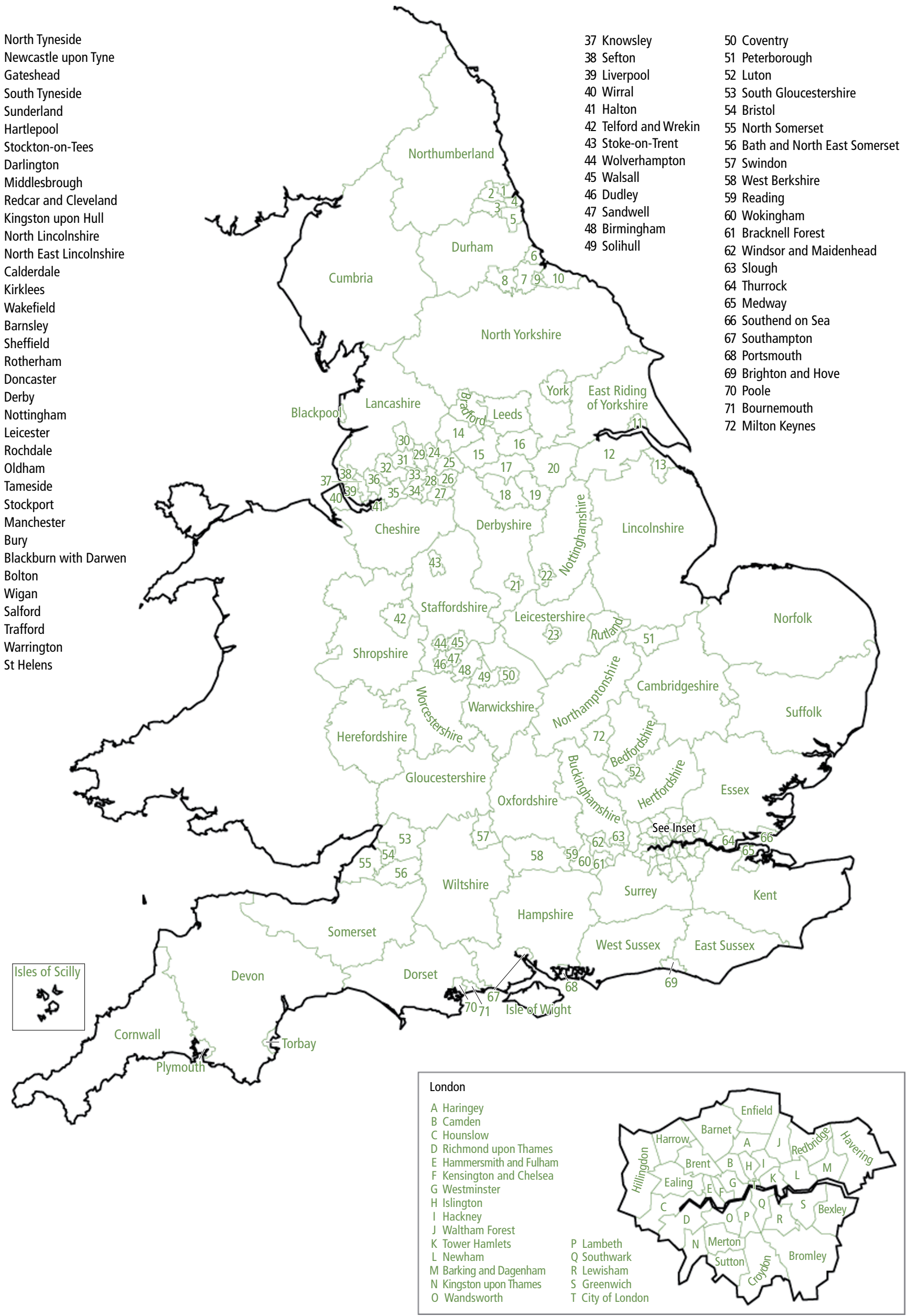